\title{
Interdisciplinary Learning and Multiple Learning Approaches in Enhancing the Learning of ESL among STEM Learners
}

\author{
Muhammad Syamil Yahya, Harwati Hashim \\ Faculty of Education, Universiti Kebangsaan Malaysia, Bandar Baru Bangi, Malaysia \\ Email: harwati@ukm.edu.my
}

How to cite this paper: Yahya, M. S., \& Hashim, H. (2021). Interdisciplinary Learning and Multiple Learning Approaches in Enhancing the Learning of ESL among STEM Learners. Creative Education, 12, 1057-1065.

https://doi.org/10.4236/ce.2021.125078

Received: April 7, 2021

Accepted: May 24, 2021

Published: May 27, 2021

Copyright $\odot 2021$ by author(s) and Scientific Research Publishing Inc. This work is licensed under the Creative Commons Attribution International License (CC BY 4.0).

http://creativecommons.org/licenses/by/4.0/

\section{(c) (i) Open Access}

\begin{abstract}
As the world is moving towards Industrial Revolution 4.0 (IR 4.0), the need to develop creative thinking is demonstrated in Science, Technology, Engineering and Mathematics (STEM) curriculum. Students are prepared to nurture the problem-solving skills which are vital in their future STEM career. As this field is needed globally, communication skills are as important as content knowledge. Generally known as lingua franca, acquiring English enables people to communicate globally, hence broadening their chance of having their career. Thus, developing critical thinking should be in line with developing the language skills especially for the English as second language (ESL) learners. This paper views the interdisciplinary learning and multiple learning approaches that could help student's attainment in STEM and ESL. This paper proposes the collaboration among ESL and STEM teachers to conduct interdisciplinary learning experience by the application of student-centred learning approaches such as inquiry-based learning, project-based learning, blended learning and problem-based learning. The proposed learning approaches are the bridge to integrate ESL and STEM disciplines in interdisciplinary learning and it provides advantages for teachers and learners. Hence, it is accepted to promote and implement interdisciplinary learning in the current curriculum environment.
\end{abstract}

\section{Keywords}

ESL, STEM, Interdisciplinary Learning, Multiple Learning Approaches, Inquiry-Based Learning, Project-Based Learning,

Blended Learning and Problem-Based Learning

\section{Introduction}

Students in science, technology, engineering and mathematics (STEM) fields 
whose first language is not English are facing challenges to compete globally (LaCosse et al., 2020). Acquiring English is important as a means of communication to convey ideas, sharing the content knowledge and having a discussion among team members from various backgrounds and countries (Apple et al., 2020). It is merely impacting their performance in the work field if the communication does not work accurately. Although the oral communication skills are essential and viewed as one of critical components in today's success, the STEM learners mistakenly feel that their technical skills and knowledge alone are sufficient (Apple et al., 2020). In fact, the daily task in their field requires them to communicate frequently, and most of it requires English as the lingua franca. Thus, learning English as a second language (ESL) must be regarded as important as learning content knowledge.

The research by Engelbret (2015) highlighted the integration of STEM approach in teaching Science and English for ESL learners. PBL was implemented in the intervention lesson where students were given a Science project entitled "Water Quality of Minnesota Wetland". Interestingly, ESL teachers and Science teachers collaborated to conduct the lesson. As each of them has their own niche knowledge, the collaboration is much needed to ensure students would understand the content knowledge and to ensure the communication is happening the way it is supposed to be. The collaboration between STEM teachers and ESL teachers is also suggested in MacKinnon et al. (2017) research. The researchers suggested that communication and discussion between ESL teachers and mainstream teachers should occur regularly as they complement each other in interdisciplinary learning. Adding that, Engelbret (2015) mentioned that the focus on language in science could improve students' ability to convey their knowledge both in oral and written form. It is also suggested that interdisciplinary learning motivates students to have careers in STEM in the future (Stohlmann et al., 2012). Therefore, it can be concluded that integrating multiple disciplines could benefit students in language and content development.

Bridging the disciplines of STEM and ESL, the suitable learning approaches are needed. By nature, STEM is being practiced interdisciplinary and highlights the real problem-solving context (Asghar et al., 2012). Breiner et al. (2012) also state that STEM naturally integrates various disciplines rather than compartmentalized them. Kong et al. (2020) review the prominent approaches in STEM learning which are inquiry-based learning, project-based learning, blended learning, and problem-based learning. The approaches are dominantly applied in previous research interventions. All the mentioned approaches are basically student-centred. This is parallel with one of the six core of STEM integration, which is implementing student-centred teaching and learning activities (Johnson et al., 2015). Similarly, the current language learning transforms from traditional teacher-centred approach to student-centred approach (Muniandy \& Shuib, 2016). It is often being associated with active learning which involves students' participation through activities that demand them to work together (Athirah et al., 2020). In line with that, Unin and Bearing (2016) regard language stu- 
dent-centred approach as a deep learning process to understand the knowledge that involves active participation of the learners. With that being said, it can be concluded that student-centred learning helps students to develop their critical thinking as well as their language skills simultaneously.

Hence, this paper discusses the concept and application of interdisciplinary learning and multiple learning approaches in enhancing the learning of ESL among STEM learners. The following sections also discuss the benefits and impacts of the learning process for pedagogical and the suitability of interdisciplinary learning in the current curriculum environment.

\section{Interdisciplinary Learning}

Interdisciplinary learning approach becomes important in modern curriculum. The interdisciplinary approach synthesizes various disciplines and puts teachers and students in collaboration to enhance the learning experience (Jones, 2010). Jacobs (1989) also states interdisciplinary approach is a fusion of disciplines that influence students' lives, and it is important for them to see the strength of each discipline in a connected way. Possibly the comparison between interdisciplinary learning and multidisciplinary learning would offer a clearer perspective. Ivanitskaya et al. (2002) refer multidisciplinary learning as the involvement of several disciplines but not necessarily in an integrated manner. By contrast, Rowntree (1981) defines interdisciplinary learning as a lesson that includes multiple disciplines from different subjects in mutual interaction and significantly impacts one another. In a nutshell, interdisciplinary learning could happen between any disciplines, involving teachers' collaboration from various disciplines and integrated systematically to benefit the students in the intended disciplines.

Integrating ESL in the STEM context will definitely benefit the students. In this context, STEM learners should be able to critically see the need of learning ESL as a co-dependent element in securing their future in the STEM career field. Apple et al. (2020) state that the interdisciplinary approach increases the motivation and language learning attitudes of STEM students in learning ESL. Supporting this, interdisciplinary approach also expands students' understanding and attainment in the intended disciplines and improves their communication skills (Jones, 2010). As English is seen as important language in many science disciplines, lack of competencies in the language would set the learners back and limit their abilities and performance (Delgado et al., 2019). Thus, it can be concluded that ESL competency among STEM learners is vital in acquiring the content knowledge and serving the purpose of their career needs which could be attained through interdisciplinary learning.

Despite the advantages, it also has drawbacks such as the time consumed to prepare the lesson and the confusion of the knowledge contents during the integration (Jones, 2010; Jacobs, 1989). Hence, Jacobs (1989) suggested two main criteria for the teachers to implement the interdisciplinary learning which are:

- Teachers must carefully plan the design of the lesson which encompasses se- 
quence, cognitive process to develop thinking skills, indicators of attitudinal change and systematic evaluation method.

- Teachers must use both the basic discipline of both fields and integrate them to create a meaningful learning experience for the students.

Based on the criteria, the student-centred learning approaches are most applicable in interdisciplinary learning as it enables students to enhance their critical thinking skills while acquiring the other skills as well. Hence, the next section discusses the multiple learning approaches as viewed in Kong et al. (2020) research.

\section{Multiple Learning Approaches in Interdisciplinary Learning}

Integrating ESL and STEM disciplines requires learning approaches that can fulfil the implementation needs of both disciplines. Hence, inquiry-based learning (IBL) is one of the suitable approaches to bridge the disciplines. It is viewed as the approach that focuses on problem-solving and encourages students to develop their problem-solving skills (Pedaste \& Sarapuu, 2006). It emphasizes students' role as autonomous learners to explore the new knowledge and participate actively in the process (De Jong \& Van Joolongen, 1998). Supporting this, IBL aims to enhance students' higher order reasoning skills (Galvez, 2019). This is why this approach is mainly used in integrating STEM elements and improving ESL learners' language acquisition. The research from Galvez (2019) integrated the use of Information and Communication Technology (ICT) in teaching language as a tool to encourage students' engagement. Significantly, the application of ICT in the teaching and learning process for ESL learners shares the same value of STEM disciplines, which is to promote technology exploration in integrating interdisciplinary knowledge (Lai, 2018). The use of Skype and OneNote as collaborating tools, as well as Google search engine enable students to gather the information by themselves, rather than being taught by the teachers (Baharin \& Kamarudin, 2018) (Figure 1).

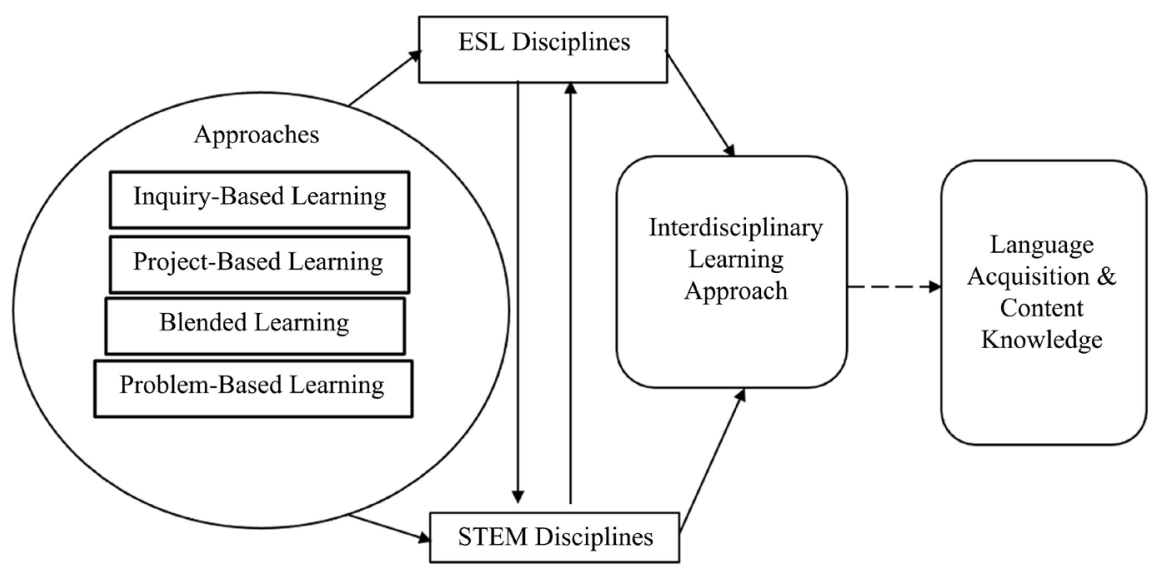

Figure 1. Conceptual framework of STEM and ESL interdisciplinary approach. 
On the other hand, Sehlaoui (2018) states that project-based learning (PBL) characteristics use driving questions in its approach making it important in interdisciplinary learning. As a student-centred approach, students are able to acquire a deeper understanding of the knowledge through the exploration process and real-world situations and challenges. Similarly, integrating the disciplines of STEM also requires students to be exposed and have a rich understanding of real-world problems (Glancy \& Moore, 2013). The outcome of the approach would of course be benefiting students in acquiring ESL and nurturing the skills and knowledge from STEM (Engelbret, 2015). Application of ICT in the project innovates this approach to be more reachable, applicable and interesting. The research showed that ICT helps students to communicate, look for information and share them in visual context (Baharin \& Kamarudin, 2018). Apart from content knowledge, language acquisition is being incorporated in a meaningful, interesting way which makes students to be more motivated (Aiedah \& Lee, 2012).

In cooperating ICT with traditional face-to-face classroom, blended learning is the new approach that caught the attention of educators from all levels. In teaching STEM, it involves the use of ICT as teaching aids (Ministry of Education, 2016). The same discipline is applied to teach ESL learners as physical classroom lessons is supported by online learning to promote constructive learning and students-centred environment (Quvanch \& Na, 2020). It supports students with different abilities to learn in a flexible, interactive and communicative manner. The research from Quvanch and $\mathrm{Na}$ (2020) also found that blended learning has been used much by the teachers as it gives a positive impact to improve the students' writing skills. This is important as writing is a crucial communicative medium to express the idea and thought or else, students would be left behind (Adas \& Bakir, 2013).

Problem-based Learning in STEM integration provides opportunities for students to solve real situation problems in a collaborative manner (Ministry of Education, 2016). Likewise, this approach could also be applied to improve students' course content and language acquisition at the same time. The use of Creative Problem Based Learning model (CBPL) has proven its effectiveness for English learning as by nature, it also follows the principle of STEM discipline to encourage students to engage and become good problem solvers (Hersulastuti et al., 2019). Supporting this, the research also indicates that essays written by the students that follow the PBL intervention are richer with knowledge, support and argument (Othman \& Shah, 2013).

\section{Suggestion for Pedagogical Implications}

Based on the discussion, it could be concluded that applying interdisciplinary learning with multiple learning approaches could benefit both students and teachers in ESL and STEM courses (Deneme \& Ada, 2012). As beneficial it is, teachers' role is important to determine the interdisciplinary learning effective- 
ness (Wicklein \& Schell, 1995). Therefore, here are suggestions that could help in the implementation of the interdisciplinary learning:

- Teachers from both fields should spend their time together incorporating the disciplines in their lessons. The process might be time consuming and confusing at the beginning, but following the criteria of interdisciplinary as stated in the previous section will really help them to achieve the goals.

- The student-centred multiple approaches that were discussed earlier are important to bridge the ESL and STEM disciplines. Teachers have multiple options of approaches to be applied pertaining to their students' background, resources accessibility, and classroom situations. Teachers' creativity will indeed be needed in manipulating the approaches to become interesting and meaningful. As ESL and STEM share the same nature, integrating the disciplines in the right manner enables students to practice the language in the STEM-related project and lesson. At the end, students will enjoy, understand and appreciate the value of the lessons.

- Teachers should be familiarized with the concept and implementation of the new learning approach. The view of ESL and STEM is conventionally learned in silos, so this perspective needs to be gradually changed. Sufficient training to help teachers to comprehend the whole picture of interdisciplinary learning should be provided by the education institution, beginning from teacher training level. In addition, collaboration between teacher training institutions, polytechnics, and universities will also enhance the understanding of the learning concept in various levels of education.

- The role of teachers to implement it at the micro level could open bigger opportunities for recognition from the policy maker. For example, Science and Mathematics teachers in a school could sit together with English teachers for collaboration learning that integrates disciplines of content knowledge and language learning. The outcome from the students' performance could be an eye opener to the policy maker as well as the other educators of various levels.

In conclusion, the novelty of the approach could be normalized in the curriculum environment through collaboration of educators at all levels. ESL and STEM should be seen as correlated subjects and positively impact the students' future careers. The positive view towards interdisciplinary learning allows learners to enjoy the learning process in an authentic manner.

\section{Conclusion}

To conclude, student-centred learning approaches are the heart of interdisciplinary learning. It appears that options of multiple approaches help teachers to enhance ESL proficiency among STEM learners by adapting them in authentic and meaningful manner. Both disciplines help pupils in their cognitive ability, and ESL adds on the students' value in terms of communication which is a critical aspect in the global career market. So, ESL learning should be seen as an im- 
portant discipline to be incorporated with STEM in interdisciplinary learning. As a result, teachers are able to create meaningful, authentic and real-world learning experiences for the students which eventually reflect their performance in language and content knowledge. It is admissible to say that applying the student-centred learning approaches to integrate ESL and STEM disciplines is relevant in the current situation for future needs, and we have the responsibility to ensure it is being implemented as it is supposed to be.

\section{Acknowledgements}

The authors would like to thank Universiti Kebangsaan Malaysia under the Research Grant number 1) GG-2021-003 and 2) GG-2019-077 for supporting this project.

\section{Conflicts of Interest}

The authors declare no conflict of interest regarding the publication of this paper.

\section{References}

Adas, D., \& Bakir, A. (2013). Writing Difficulties and New Solutions: Blended Learning as an Approach to Improve Writing Abilities. International Journal of Humanities and Social Science, 3, 254-266.

Aiedah, A. K., \& Lee, K. C. (2012). Application of Project-Based Learning in Students' Engagement in Malaysian Studies and English Language. Journal of Interdisciplinary Research in Education (JIRE), 2, 37-46.

Apple, M. T., Falout, J., \& Hill, G. (2020). The Relationship between Future Career Self Images and English Achievement Test Scores of Japanese STEM Students. IEEE Transactions on Professional Communication, 63, 372-385. https://doi.org/10.1109/TPC.2020.3029662

Asghar, A., Ellington, R., Rice, E., Johnson, F., \& Prime, G. M. (2012). Supporting STEM Education in Secondary Science Contexts. Interdisciplinary Journal of Problem-Based Learning, 6, Article 4. https://doi.org/10.7771/1541-5015.1349

Athirah, N., Nasir, M., \& Aziz, A. A. (2020). Implementing Student-Centered Collaborative Learning When Teaching Productive Skills in an ESL Primary Classroom. International Journal of Publication and Social Studies, 5, 44-54. https://doi.org/10.18488/journal.135.2020.51.44.54

Baharin, N., \& Kamarudin, N. (2018). STEM ASEAN Project to Promote 21st Century Teaching and Learning. Learning Science and Mathematics, No. 13, 98-114.

Breiner, J. M., Harkness, S. S., Johnson, C. C., \& Koehler, C. M. (2012). What Is STEM? A Discussion about Conceptions of STEM in Education and Partnerships. School Science and Mathematics, 112, 3-11. https://doi.org/10.1111/j.1949-8594.2011.00109.x

De Jong, T., \& Van Joolingen, W. R. (1998). Scientific Discovery Learning with Computer Simulations of Conceptual Domains. Review of Educational Research, 68, 179-201. https://doi.org/10.3102/00346543068002179

Delgado, S. J., Collazo Reyes, J. J., Gómez Dopazo, S. I., Rodríguez Díaz, E. A., \& Torres Arroyo, K. M. (2019). Hispanic ESL Science Majors Need More Practice Using English for Scientific Purposes. Journal of Hispanic Higher Education, in press. 
https://doi.org/10.1177/1538192719852025

Deneme, S., \& Ada, S. (2012). On Applying the Interdisciplinary Approach in Primary Schools. Procedia-Social and Behavioral Sciences, 46, 885-889.

https://doi.org/10.1016/j.sbspro.2012.05.217

Engelbret, C. J. (2015). The Confluence of STEM Education and Language Learning: Curriculum Integration to Benefit Language Learners. School of Education Student Capstone Theses and Dissertations, 250. https://digitalcommons.hamline.edu/hse_all/250

Galvez, S. (2019). From Traditional to Practical: A Twist Using Inquiry Based Instruction in ESL Learning. https://doi.org/10.2139/ssrn.3488896

Glancy, A. W., \& Moore, T. J. (2013). Theoretical Foundations for Effective STEM Learning Environments. School of Engineering Education Working Papers, Paper 1.

Hersulastuti, H., Setiyadi, D. P., \& Riyadi, I. (2019). Implementing Creative Problem-Based Learning Model in English Classroom: Students and Teachers Voices. 8th UNNES International Conference on ELTLT, Indonesia: Universitas Negeri Semarang, October 2019, 81-89.

Ivanitskaya, L., Clark, D., Montgomery, G., \& Primeau, R. (2002). Interdisciplinary Learning: Process and Outcomes. Innovative Higher Education, 27, 95-111. https://doi.org/10.1023/A:1021105309984

Jacobs, H. H. (1989). Interdisciplinary Curriculum: Design and Implementation. Alexandria, VA: Association for Supervision and Curriculum Development.

Johnson, C. C., Peters-Burton, E. E., \& Moore, T. J. (Eds.) (2015). STEM Road Map: A Framework for Integrated STEM Education. New York: Routledge. https://doi.org/10.4324/9781315753157

Jones, C. (2010). Interdisciplinary Approach-Advantages, Disadvantages, and the Future Benefits of Interdisciplinary Studies. ESSAI, 7, Article 26.

Kong, S. F., Effendi, M., \& Matore, E. M. (2020). STEM Approaches in Teaching and Learning Process: Systematic Literature Review (SLR). Jurnal Pendidikan Sains Dan Matematik Malaysia, 10, 29-44.

LaCosse, J., Canning, E. A., Bowman, N. A., Murphy, M. C., \& Logel, C. (2020). A Social-Belonging Intervention Improves STEM Outcomes for Students Who Speak English as a Second Language. Science Advances, 6, eabb6543.

https://doi.org/10.1126/sciadv.abb6543

Lai, C. S. (2018). Using Inquiry-Based Strategies for Enhancing Students' STEM Education Learning. Journal of Education in Science, Environment and Health, 4, 110-117

MacKinnon, G., Greene, K., Rawn, E., Cressey, J., \& He, W. (2017). Employing STEM Curriculum in an ESL Classroom: A Chinese Case Study. K-12 STEM Education, 3, 143-155.

Ministry of Education (2016). Panduan Pelaksanaan Sains, Teknologi, Kejuruteraan dan Matematik (STEM) Dalam Pengajaran dan Pembelajaran. Kementerian Pendidikan Malaysia, Bahagian Pembangunan Kurikulum.

Muniandy, J., \& Shuib, M. (2016). Learning Styles, Language Learning Strategies and Fields of Study among ESL Learners. Malaysian Journal of ELT Research, 12, 1-19.

Othman, N., \& Shah, M. I. A. (2013). Problem-Based Learning in the English Language Classroom. English Language Teaching, 6, 125-134. https://doi.org/10.5539/elt.v6n3p125

Pedaste, M., \& Sarapuu, T. (2006). Developing an Effective Support System for Inquiry Learning in a Web-Based Environment. Journal of Computer Assisted Learning, 22, 
47-62. https://doi.org/10.1111/j.1365-2729.2006.00159.x

Quvanch, Z., \& Na, K. S. (2020). A Review on Impact of Blended Learning on the English Writing Skills. Innovative Teaching and Learning Journal (ITLJ), 4, 41-50.

Rowntree, D. (1981). A Dictionary of Education. Harper \& Row Pub.

Sehlaoui, A. S. (2018). Teaching ESL and STEM Content through CALL: A Research-Based Interdisciplinary Critical Pedagogical Approach. Rowman \& Littlefield.

Stohlmann, M., Moore, T. J., \& Roehrig, G. H. (2012). Considerations for Teaching Integrated STEM Education. Journal of Pre-College Engineering Education Research (J-PEER), 2, Article 4. https://doi.org/10.5703/1288284314653

Unin, N., \& Bearing, P. (2016). Brainstorming as a Way to Approach Student-Centered Learning in the ESL Classroom. Procedia-Social and Behavioral Sciences, 224, 605-612. https://doi.org/10.1016/j.sbspro.2016.05.450

Wicklein, R. C., \& Schell, J. W. (1995). Case Studies of Multidisciplinary Approaches to Integrating Mathematics, Science, \& Technology Education. Journal of Technology Education, 6, 59-76. https://doi.org/10.21061/jte.v6i2.a.5 